\title{
A NEW SPECIES OF CYATHODES (EPACRIDACEAE) FROM TASMANIA
}

by S.J. Jarman

Botany Department, Lniversity of Tasmania

(communicated by Dr. R. L. Growden)

(with 1 text figure)

\section{ABSTRACT}

Cyathodes nitida (subfamily Styphelieae) is a new species, endemic to Tasmania.

\section{DESCRIPTION}

Cyathodes nitida S.J. Jaman, sp. nov.

Frutex humilis, $15-40 \mathrm{~cm}$ altus, ramis patentibus et erectis, similis habitu Cyathodi petiotari. Caules juvenes minute pubescentes, vetustiores scabri. Folia alterna in caulibus novellis sub-erecta et conferta sed in vetustiorbus saepe laxa et irregulariter patentia; lamina integra 4 - $10 \mathrm{~mm}$ longa (acumine pungenti incluso) et 1.5 - $2 \mathrm{~mm}$ lata angusta-oblonga usque angusta-1anceolata, margo valde recurvus, basis rotundata, apex acumine gracili pungenti $0.5-1 \mathrm{~mm}$ longo sed in foliis primis cuiusque anni formatus acutatus et scariosus sed non pungens, supra plus minusve nitida subtus hebetata sed non glauca, jarallelinerva subtus 3 nervis omnibus simplicibus, si supra apparet tantum in forma sulci solitarii non profundi; jetiolus minute puberulus $1-1.5 \mathrm{~mm}$ longus. Flores solitarii in axillis foliorum versus extramitates ramorum. Bractae ciliatae, iracta suprema calyce circa 3-plo brevior. Sepala late elliptica $\overline{2}-\overline{3} \mathrm{~m}$ longa apice rotundata. Corolla alba; cubus calycem vix superans bulbosus infra pilis brevilus, lobis patentibus tubo brevioribus plerumque gladbris vel interdum pilis sparsis. Antherae semi-inclusae. Discus 5-lobus. Ovarium 5-loculare. Fructus drupaceus 2.j- $4 \mathrm{~mm}$ profundus $4-8 \mathrm{~mm}$ in diametro depressissinus ruber-niger facie laevi nitida.

A low shrub resemb1ing $C$. petiozaris in habit, with branches spreading and erect, $15-40 \mathrm{~cm}$ high. Young stems puberulent, older ones with rough, scaly bark. Leaves alternate, sub-erect and crowled on young stems but often loose and spreading irregularly on older stems; blade entire, 4 - $10 \mathrm{~mm}$ long (including the pungent point), $1.5-2 \mathrm{~mm}$ broad, larrow-oblong to narrow-lanceolate, margin recurved, base rounded, upex forming a slender pungent point, $0.5-1 \mathrm{~mm}$ long, but on the first formed leaves of each year'; growth acute and scarious but not pungent, the upper surface somewhat shiny, the lower surface dull but not glaucous, venation paralle1 with 3 unbranclied veins on the lower surface, if present on the upper surface then represented by a single, shallow groove; petiole minutely puberulent, $1-1.5 \mathrm{~mm}$ long. Flowers solitary in the axils of leaves towards the ends of the branches. Bracts ciliate, the uppermost scarcely a third the length of the calyx. Sepals broadly elliptical, 2 - $3 \mathrm{~mm}$ long, ciliate with rounded apex. Corolla white, the tube about as long as the calyx, bulbous, lith short hairs inside, lobes shorter than the tube, spreading, narrowly imbricate at the base, usually glabrous but on some plants with a few scattered hairs. Anthers half exerted. Lisk of 5 lobes. Ovary 5 locular. Fruit a drupe, very depressed, $2.5-4 \mathrm{~mm}$ deep, $4-8 \mathrm{~mm}$ in diameter, black-red, the surface smooth, shiny.

Lolotype: Lake Augusta, Tasmania, R.K. Crowden and S.J. Jarman, 10.11.1970 (University of Tasmania Herbarium, HO) . 

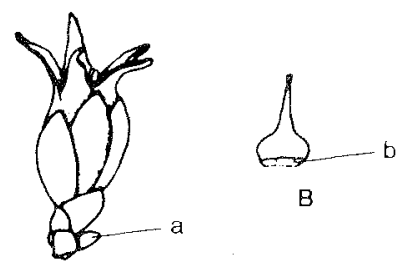

B

A
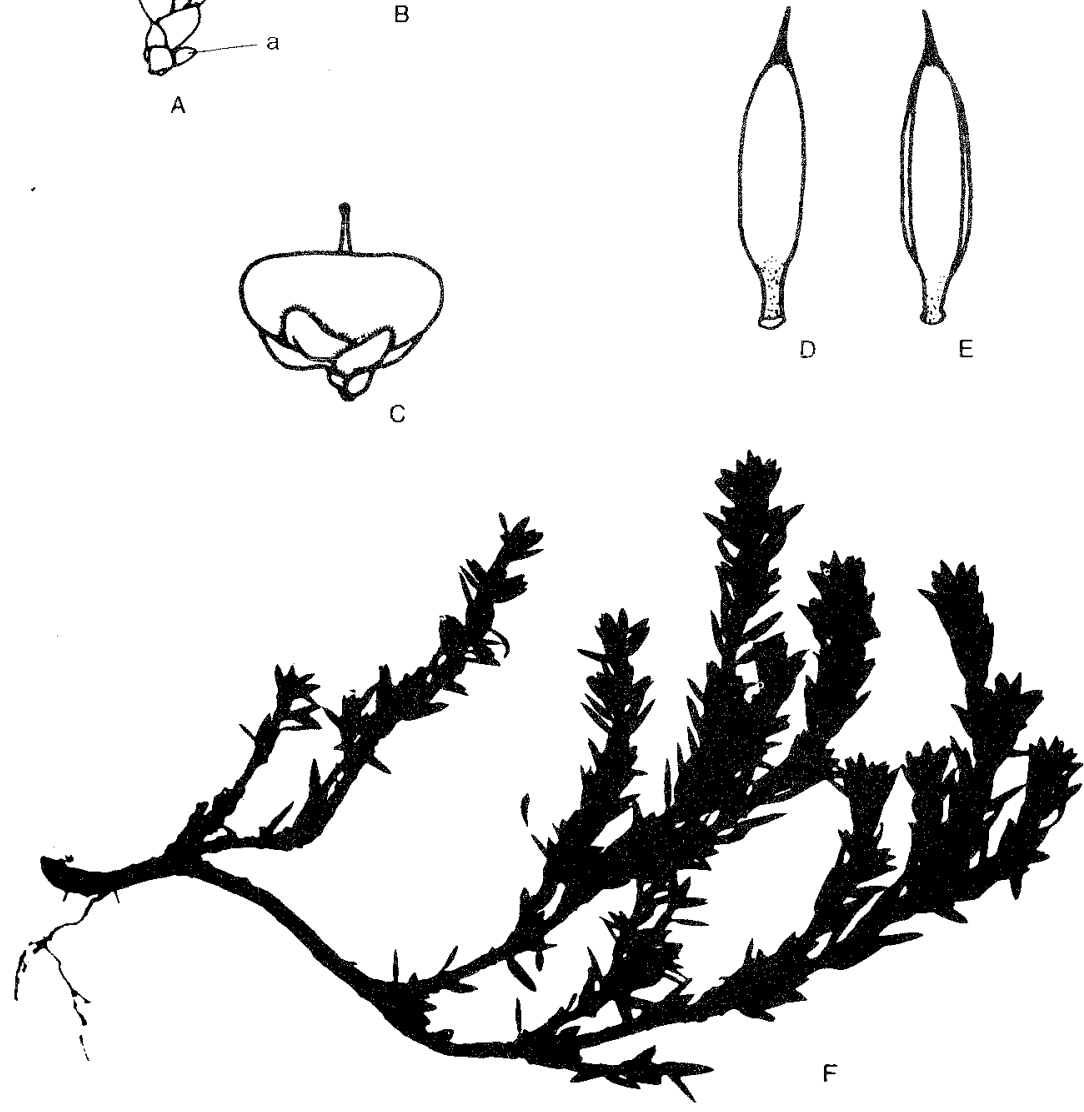

FIG. 1. - Cyathodes nitida. A. Flower, a. rudimentary bud; B. Gynoecium, b. nectar-secreting disk; C. Fruit; b. Lpper surface of leaf; E. Lower surface of leaf; F. profile of a branch. A - E. x 3.75; i. x 0.75.

COMPARISONS

Cyathodes nitida is readily distinguished from othor Tasmanian species of the genus, and is easily recognised by the very flattened, blossy, black red drupe along with the non glaucous undersurface of the leaf.

Its closest affinities are with C. petiolaris and together these two species occupy a somewhat intermediate position between the genera Cyathodes and Leucopogon. In both species the flower is solitary (although sometimes 2 or 3 are present together in $C$. petiolaris) and almost sessile. It is subtended by one bract and two bracteoles, as in species of the genus Leucopogon. In addition, a rudinentary bud is present terminating the inflorescence. This structure is unknown in other Cyathodes 
species but is commonly found in species of Leucopogon. because of its small size, the rudimentary bud appears axillary on the inflorescence, and if it is removed, its subtending bract overlaps the bracts of the properly formed flower. The peduncle then appears as a multibracteate pedicel typical of the genus Cyathodes. of C. petiolaris Bentham (1869) writes "ihis species has the inflorescence of Leucopogon, and ought, perhaps, to be transferred to that genus; but the fruit is much more pulpy than in any Leucopogon, and the aspect and foliage are quite those of Cyathodes." This statement is also applicable to $C$. ilitida, whose position in the genus Cyathodes is strengthened by the absence of bearded corolla lobes which are typical of $C$. petiolaris and of the genus Leucopogon.

C. nitida is similar in habit to C. petiotamis and occupies a similar altitude range (although the two species have not been found together in the same plant community). In leaf shape, $C$. mitida is similar to a distinctive variety of $C$. petiotaris (but not to typical C. petiolaris) collected from Mt. Hamilton and the Denison Range in western Tasmania. The leaves differ from this variety by their smaller size, the number of veins and the texture of the undersurface. bther differences between $C$. mitida and $C$. petiolamis include colour and surface texture of the fruits. c. nitida flowers during October and November, with the fruits ripening in February March, and remaining on the plant until the onset of winter (May - June).

\section{DISTRIBUTION AND ECOLOGY.}

This species is endemic and appears to be very localized, ht present it is known only from the Central Plateau, around Lake Augusta (at an altitude greater than $1100 \mathrm{~m})$. In this region, it grows in shallow, stony soils, in close association with Monotoca empetrifolia (Epacridaceae). These two species form part of the low shrubbery in an open heathland dominated by the taller shrub, orites acicularis (Proteaceae).

\section{ACKNOWLEDGMENTS}

I wish to thank Dr. W.M. Curtis for helpful suggestions relating to the species description, and Mr. R.G. ilood (Classics Department, Eniversity of Tasmania) for his correction of the Latin translation.

\section{REFERENCES}

Benthan, G., 1869: Flora AustraZiensis. Vo1. 4., Lovel1, l:eeve \& Co., London. 